\title{
Correction to: Prevalence and molecular characterization of Salmonella enterica serovar Typhimurium from ice and beverages in Jakarta, Indonesia
}

Diana E. Waturangi', Eko Wiratama and Audora Sabatini Theresia

\section{Correction to: BMC Res Notes (2019) 12:45}

https://doi.org/10.1186/s13104-019-4065-y

Following publication of the original article [1], the authors reported that the family name of one of the authors was omitted. In this Correction the incorrect and correct author name are shown. The original publication of this article has been corrected.

Originally the author name was published as:

- Audora Sabatini

The correct author name is:

- Audora Sabatini Theresia

\section{Publisher's Note}

Springer Nature remains neutral with regard to jurisdictional claims in published maps and institutional affiliations.

Received: 29 January 2019 Accepted: 29 January 2019

\section{Reference}

1. Waturangi DE, et al. Prevalence and molecular characterization of Salmonella enterica serovar Typhimurium from ice and beverages in Jakarta, Indonesia. BMC Res Notes. 2019;12:45. https://doi.org/10.1186/s1310 4-019-4065-y. 